\title{
Residual Stress Analysis in Orthogonal Cutting of AISI 1020 Steel
}

\author{
O. Bhatkar ${ }^{1}$, S. Sakharkar ${ }^{2}$, V. Mohan ${ }^{3}$, R. Pawade ${ }^{4}$ \\ ${ }^{1}$ PGStudent, Finolex Academy of Management \& Technology, Ratnagiri, India \\ ${ }^{2}$ PG Student, Dr. Babasaheb Ambedkar Technological University, Lonere, India \\ ${ }^{3}$ Associat Professor, Finolex Academy of Management \& Technology, Ratnagiri, India \\ ${ }^{4}$ Associate Professor, Dr. Babasaheb Ambedkar Technological University, Lonere, India \\ \{ssakharkar157@gmail.com,vmm@famt.com\}
}

\begin{abstract}
The aim of research work is to analyze residual stresses generated during shaper machining. This paper presents the simulation of single point cutting process by finite element method and compared with experimental work results. Taguchi L9 experimental design is used to obtain effective process parameters of rake angle, depth of cut and cutting speed. High speed cutting tool steel is used for orthogonal cutting of AISI 1020 steel on shaper machine. The residual stresses are measured by X-ray sine ${ }^{2} \psi$ diffraction method and finite element software used to simulate residual stress analysis. In Taguchi designed experimentation rake angle $12^{\circ}$, depth of cut $1 \mathrm{~mm}$, and cutting speed $220 \mathrm{~m} / \mathrm{min}$ has been found optimum cutting parameter for optimize compressive residual stresses.
\end{abstract}

Keywords: Residual stresses, orthogonal cutting, X-ray diffraction, FEM

\section{Introduction}

Metal cutting is the one of the most widely used operation in manufacturing industry and it has lots of research investigation in both academic and industrial sectors. Cutting forces, temperatures, surface finish and stress distributions are the more important final prediction factors for designing tool geometry and optimizing cutting conditions. The surface quality of product has a main role in developing product characteristics. Surface quality of product is mainly categorized into the machined product surface roughness, microstructure and residual stresses. The residual stresses are an evident in surface roughness and play a decisive role for final product manufacturing.

Residual stresses or locked in stresses are those stresses which existing within a body in the absence of external loading or thermal gradient. These residual stresses are existing in structural material or component which at rest or without application of any service or external load. The value of residual stress is higher near to surface of component and decreases as increase in depth. These residual stresses are may be tensile or compressive and layered differently with change in machining parameters such as depth of cut, cutting tool geometry, contact conditions, chip- workpiece/ tool- workpiece contact. The compressive residual stresses are more important for product performance and its life which promoted service and prevent crack nucleation but tensile residual stresses led to premature failure, distortion and corrosion [1].

A few of research studies are available in machining on shaper tools. Shaper mainly used to make keyways in the boss of pulley or gear, dovetail slides, internal spines and gear teeth with form tool [2]. During shaper machining operation a large amount of force is exerted on machined surface in short time. AISI 1020 steel material has huge demand in industrial application. This steel properties are well responds to cold working and heat treatment operations therefore it used in shafts, lightly stressed gears, hard wearing surfaces, pins, chains bulkheads of ships.Saoubhi et al. [3] investigated residual stress analysis in orthogonal machining of AISI 316L steels. They found that temperature in machining zone associated with cutting forces which enabled the physical mechanism for generation of residual stresses. The depth of residual stresses was determined by X- ray diffraction method. The effects of cutting condition and too nature analysed for residual stresses with thermal and mechanical event testing. Henriksen [4] concluded that physically attributed residual stresses in cutting mainly because of mechanical effects which generated due to force exerted on cutting tool to the workpiece during machining process and thermal stresses due to change in heat generation.

B. Iyer, S. Nalbalwar and R. Pawade (Eds.)

ICCASP/ICMMD-2016. Advances in Intelligent Systems Research.

Vol. 137, Pp. 100-106.

(C) 2017. The authors - Published by Atlantis Press

This is an open access article under the CC BY-NC license (http://creativecommons.org/licens)es/by-nc/4.0/).

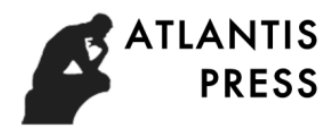


Okushimba and Kakino [5] states that the tensile residual stresses developed by heat generation/ temperature effects and compressive residual stresses by mechanical actions regarding machining operation which similar to Henriksen's conclusions.

Matsumoto et al. [6] investigated the residual stresses in machining of AISI 4340 steel and revealed that asincreasing depth of cut and feed during machining operation, machined surface was distorted and it causes to increase in residual stresses.Navas et al. [7] revealed the effect of variable cutting tool geometry on surface stresses. These residual stresses measured by X-ray diffraction method for different cutting speed, feed rate and tool nose radius. They found that residual stresses increases due to raise in cutting temperature and with increase in value of feed rate. The residual tensile stresses found less at cutting speed of $200 \mathrm{~m} / \mathrm{min}$ and $300 \mathrm{~m} / \mathrm{min}$. Neseli et al. [8] discussed in paper that surface finish affected by cutting tool geometry in metal turning operation. They concluded that tool nose radius, rake angle and approach angle were significant factors for surface finish and residual stress generation. Dogra et al. [9] investigated the effect of cutting tool geometry (tool nose radius, rake angle, groove on rake face, edge geometry) in understanding mechanics of turning and stated that an increase in chamfer angle will improved in tool life up to certain value and after that it will decreases. The size of tool edge, nose radius effect on cutting mechanism, nose radius effect of surface roughness, residual stresses of machined integrity.Bery [10] analysed superficial residual stresses in machining of AA 6061-T6511 bar stock. They used a $63.5 \mathrm{~mm}$ diameter face mill at various cutting speeds and observed a consistent pattern of residual stresses which vary between tensile and compressive forces as the cutter rotates. They adapt low cost mapping method to analyses superficial residual strain and stresses in machined components. Axir [11] developed comprehensive experimental model for predicting residual stresses profiles. The main advantage of this model over existing model was that it provided the effect of machining parameter on maximum residual stress and determined both location and depth of maximum residual stress. The experimental model described capability of predicting residual stresses in five different materials in turning operation. Liu and Guo [12] investigated effects of sequential cut and tool chip friction on residual stresses in machining layer from the first cut changes with chip thickness, cutting forces, residual stress and temperature of machined layer. Cebron et al. [13] predicted the material hardening and residual stress in machining operation. The highly hardened steel increased residual stresses by increasing feed rate and depth of cut. At cutting speed exceeding $120 \mathrm{~m} / \mathrm{min}$ visible surface cracks generated due to higher tensile stresses which attributed to combine effect of yielding and higher temperature.The literature review major revealed stress analysis for lathe and mill machine tools but it provides insufficient knowledge of orthogonal cutting on shaper tools. Therefore simulation model and experiments are conducted on shaper machine using Taguchi L9 array. The surface quality is measured in term of residual stresses. This comprehensive experimental model predict the surface and sub-surface residual stress profile in machining of AISI 1020 steel on shaper machine. This paper is focused on the finding out optimum machining parameters for orthogonal cutting process considering the effect of residual stress on fatigue life of machined component.

\section{Experimental Work}

During specimens pre-cutting operation, different residual stresses were developed in workpiece. Therefore to relieve internal and external stresses in C20 steel plate was full annealed at $860-900^{\circ} \mathrm{C}$ and cool down slowly in furnace [1]. In annealing process scales were developed due to oxidation in furnace. Therefore chemical descaling method was used and workpiece plate immersed in $20 \mathrm{~mm} \mathrm{NaOH} /$ lit for 12 hours. After that ether solution applied to remove scale on surface which loosens out due to chemical de-scaling (see fig.1). The cutting parameters were chosen from Taguchi screening method and three levels selected for variable rake angle, depth of cut and cutting speed. Taguchi design provided eighteen experimental runs including replica of experiment.

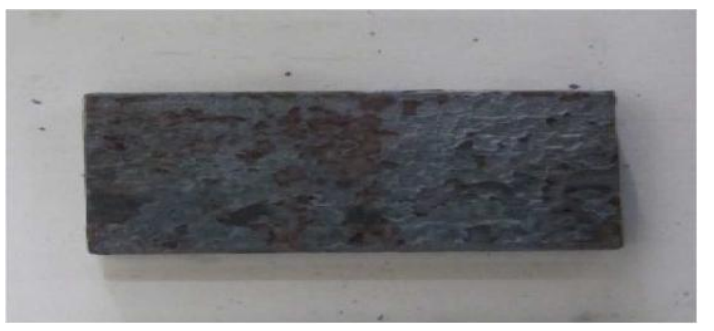

Before De-scaling

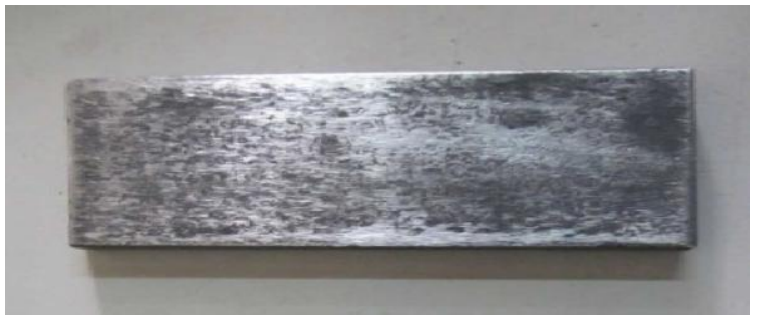

After De-scaling

Fig. 1. Schematic of AISI 1020 workpiece 
The experiments were conducted on HMT shaper machine tool (see fig.2.i). The workpiece plate AISI 1020 (C20) low carbon steel was selected having dimensions $100 \mathrm{~mm} X 50 \mathrm{mmX} 8 \mathrm{~mm}$. The chemical composition of workpiece is detailed in Table 1. Machining slots in C-20 workpiece material convention HSS tool was selected due to its high strength and toughness characteristics mention below with workpiece properties in Table 2. Nondestructive X -ray diffraction method was selected for measurement of residual stresses (see fig.2.ii). In X- ray diffraction $\sin ^{2} \psi$ technique chosen for establishing linearity in function of $\sin ^{2} \psi$ [14]

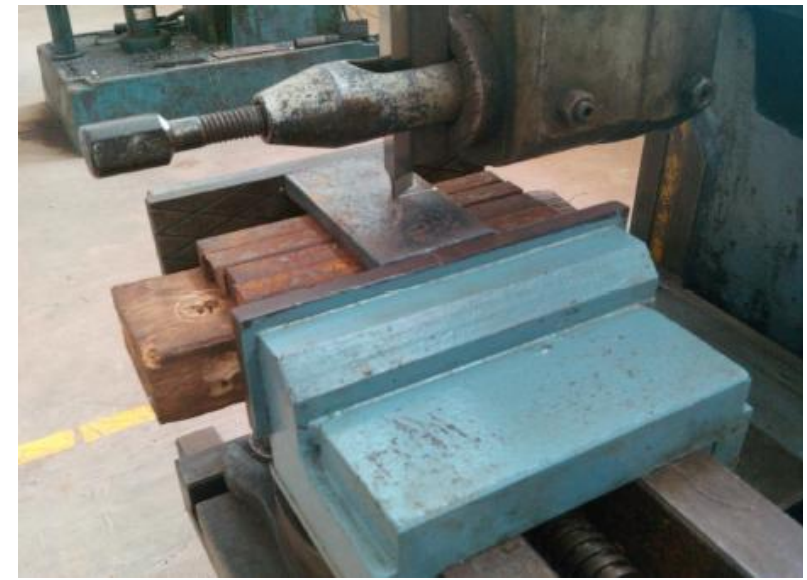

(i). Shaper Machine Tool

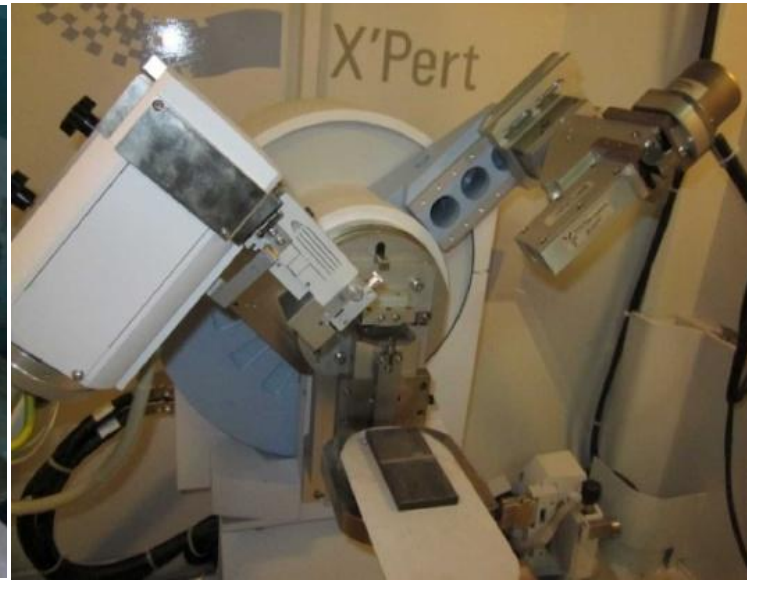

(ii). X-ray Difractometer Machine

Fig. 2. Schematics (i)Experimental setup,(ii) Residual stress measurement setup

Table1 Chemical composition of AISI1020 steel

\begin{tabular}{|l|c|c|c|c|c|}
\hline \multicolumn{7}{|c|}{ Chemical composition (wt \%) } \\
\hline Elements & C & Mn & Si & S & P \\
\hline Specified & 0.22 & 1.50 & 0.40 & 0.045 & 0.045 \\
\hline Observed & 0.20 & 0.58 & 0.23 & 0.010 & 0.022 \\
\hline
\end{tabular}

Table 2 Properties of workpiece and tool material

\begin{tabular}{|c|c|c|c|c|c|c|c|}
\hline Property & Material & $\begin{array}{l}\text { Density } \\
\left(\mathrm{g} / \mathrm{cm}^{3}\right)\end{array}$ & $\begin{array}{c}\text { Young's } \\
\text { Modulus } \\
\text { (MPa) }\end{array}$ & $\begin{array}{c}\text { Modulus } \\
\text { of Rigidity } \\
\text { (GPa) }\end{array}$ & $\begin{array}{c}\text { Yield } \\
\text { Strength } \\
\left(\mathrm{N} / \mathbf{m m}^{2}\right)\end{array}$ & $\begin{array}{l}\text { Poisson's } \\
\text { Ratio }\end{array}$ & $\begin{array}{c}\text { Coefficient of } \\
\text { Friction }\end{array}$ \\
\hline Tool & HSS & 8.14 & $207 \times 10^{3}$ & 250 & Rigid & 0.3 & 0.15 \\
\hline Workpiece & AISI 1020 & 7.85 & $210 \times 10^{3}$ & 80 & 350 & 0.305 & 0.15 \\
\hline
\end{tabular}

NX 7.5 software tool was used for finite element modelling and simulation of orthogonal cutting operation and adaptive meshing done using Hypermesh 9.0 to decrease solution errors during calculation therefore it increases accuracy of simulation and also it provided sever plastic deformation tool in metal cutting operation. The final solution was obtained using Ls-Dyna 671 to analyse generation of residual stresses. The finite element model development parameters are shown in below Table 3.

Table 3 Finite element model development parameters

\begin{tabular}{|l|l|}
\hline Mesher & Hypermesh 9.0 \\
\hline Minimum Element Size & 0.5 \\
\hline Mesh Type & Mixed (quads and trias) \\
\hline Number of Elements & 11800 \\
\hline Number of nodes & 15321 \\
\hline
\end{tabular}


In shaper operation, one degree of freedom and constrained to move along X-axis provided to shaper tool. Tool was made rigid to avoid deformation of elements of tool. In group configuration, workpiece made as master and tool as slave component. Machined model is time dependent due to stress- strain variation. Therefore this problem was fall under non-linear category. Total solution of non linear category solved in carried solution in step timer so 0.002 second increment selected to update stresses until full applied load was reached. The finite element simulation experimental model schematic is shown in Figure 3.

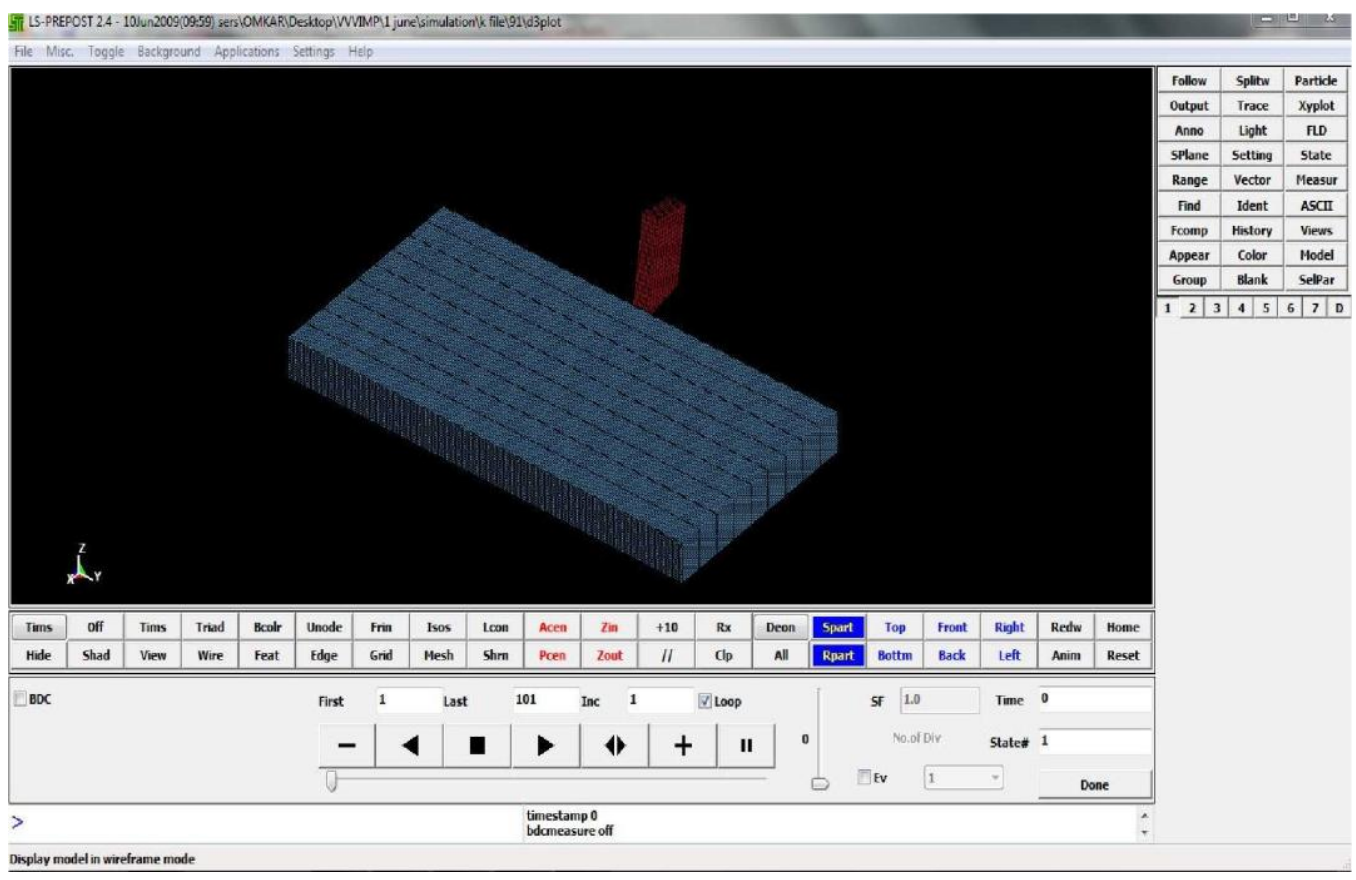

Fig. 3. Post processing window from 'LS- prepost' drop down menu

\section{Results and Discussion}

The FEM simulation conducted using Taguchi design array. This simulation data is used to compare with experimental data to validate the FEM model shown below in Table 4. Schematic 4 shows experimental worked samples of residual stress analysis.

Table 4 Comparison between simulation analysis results and experimental measurements

\begin{tabular}{|c|c|c|c|c|c|c|}
\hline $\begin{array}{c}\text { Sr. } \\
\text { No. }\end{array}$ & $\begin{array}{c}\text { Rake angle } \\
\left(\boldsymbol{\alpha}^{\mathbf{0}}\right)\end{array}$ & $\begin{array}{c}\text { Depth of } \\
\text { cut }(\mathbf{m m})\end{array}$ & $\begin{array}{c}\text { Cutting speed } \\
(\mathbf{m} / \mathbf{m i n})\end{array}$ & $\begin{array}{c}\text { Avg. } \\
\text { Compressive } \\
\text { Residual stress by } \\
\text { FEA }\end{array}$ & $\begin{array}{c}\text { Avg. } \\
\text { Compressive } \\
\text { Residual stress by } \\
\text { XRD }\end{array}$ & $\begin{array}{c}\% \\
\text { Error }\end{array}$ \\
\hline 1 & 8 & 0.5 & 220 & 290 & 249 & 14.13 \\
\hline 2 & 8 & 0.7 & 302 & 330 & 299 & 9.39 \\
\hline 3 & 8 & 1.0 & 434 & 360 & 402 & 11.67 \\
\hline 4 & 10 & 0.5 & 302 & 310 & 264 & 14.83 \\
\hline 5 & 10 & 0.7 & 434 & 300 & 330 & 10 \\
\hline 6 & 10 & 1.0 & 220 & 350 & 321 & 8.28 \\
\hline 7 & 12 & 0.5 & 434 & 295 & 261 & 11.52 \\
\hline 8 & 12 & 0.7 & 220 & 375 & 423 & 12.8 \\
\hline 9 & 12 & 1.0 & 302 & 380 & 405 & 6.57 \\
\hline
\end{tabular}




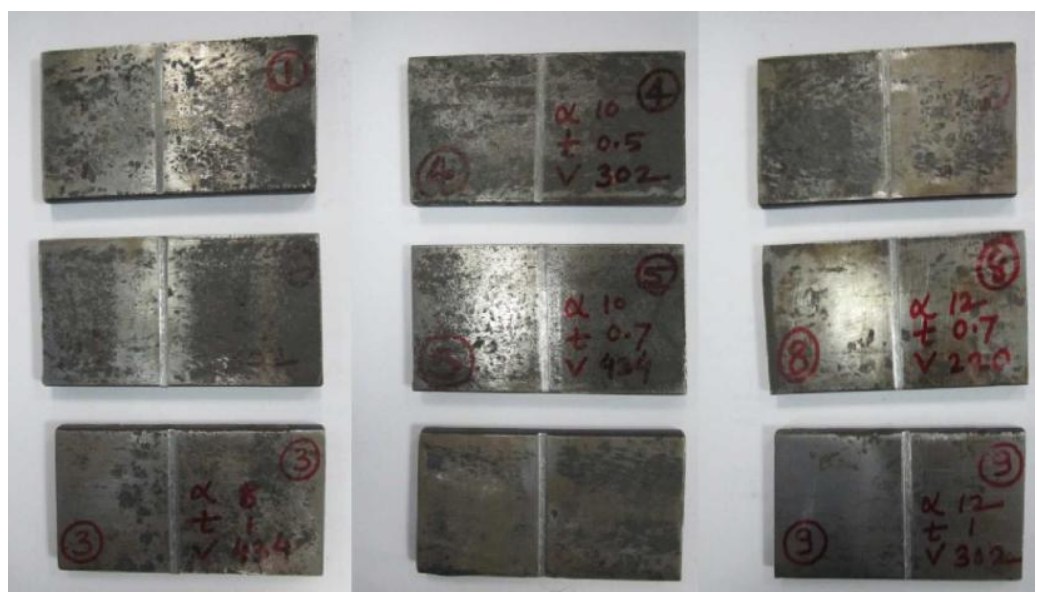

Fig. 4. Schematics of experimental worked sample

In FEA $1^{\text {st }}$ plate sample was analysed on fringe level of maximum axial residual stress shown in fig.5 and 6 below. It found that residual stresses were tensile at surface and gradually shifted to compressive value beneath the surface before stabilizing at the level corresponding to that found in work material before machining. It clearly understands that high compressive residual stresses were developed inside workpiece during orthogonal cutting process and average residual stress generated was $290 \mathrm{mPa}$ in $1^{\text {st }}$ plate (see Fig.5).
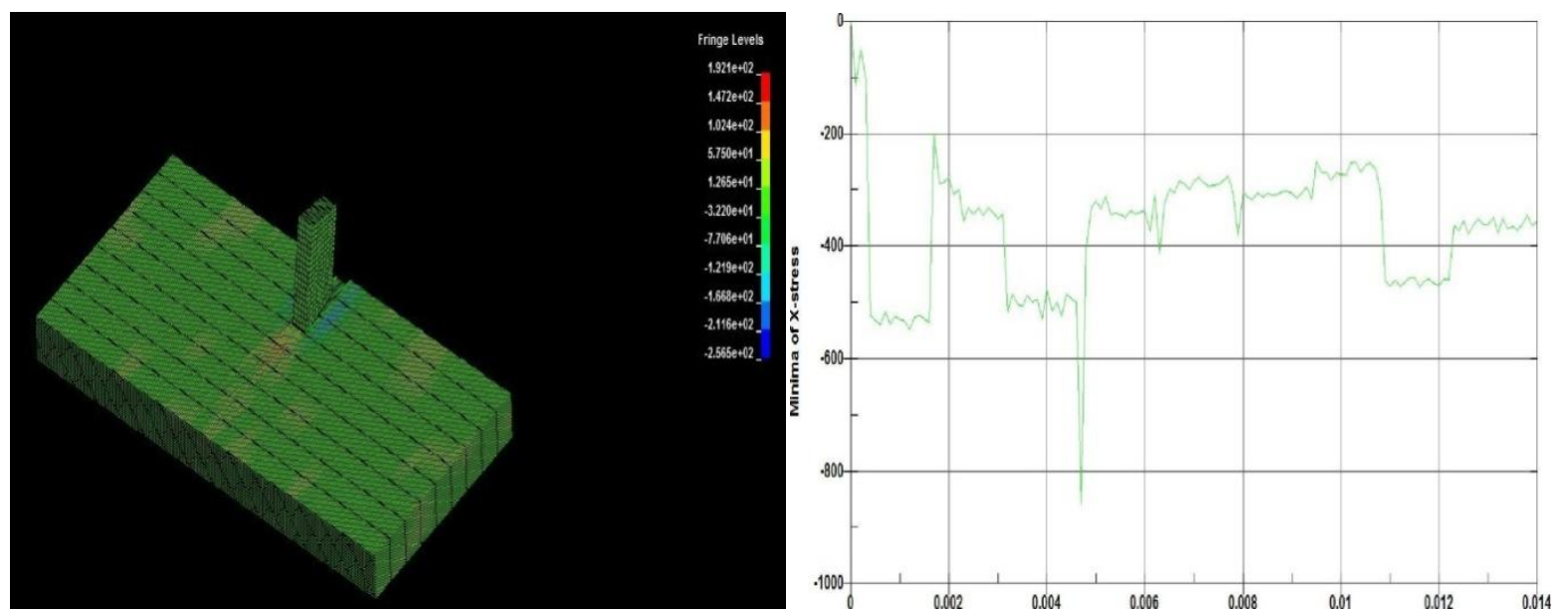

Fig. 5. Residual stress analysis results for $1^{\text {st }}$ plate

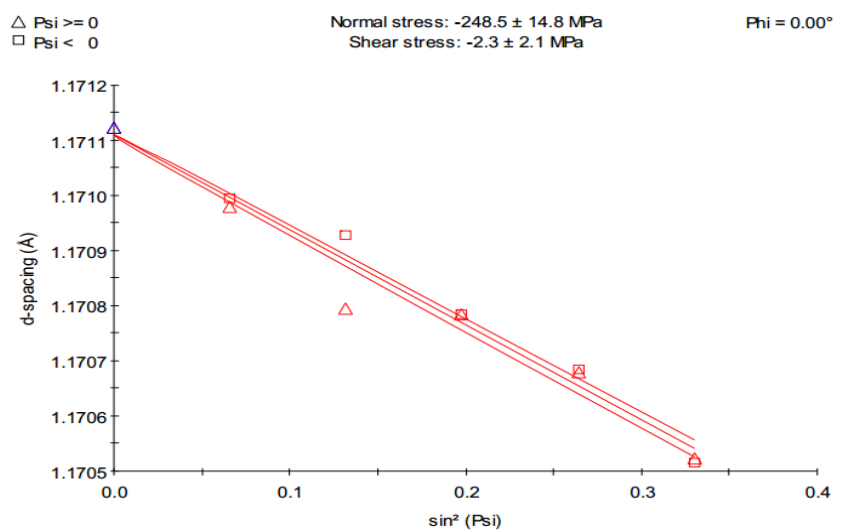

Fig. 6. XRD experimental plot of $\sin ^{2} \phi \mathrm{v} / \mathrm{s}$ d-spacing for plate 1 
The compressive residual stresses developed during shaping of workpiece and this compressive residual stresses increases fatigue life of component [4-6]. It assisted to develop quality characteristic of product, therefore larger the better chosen for $\mathrm{S} / \mathrm{N}$ ratio and means. The Taguchi design response table of residual stress is shown in Table 5.

Table 5 Response table for compressive residual stress

\begin{tabular}{|l|l|l|l|l|l|l|}
\hline & \multicolumn{3}{|l|}{ Signal to Noise ratio } & Means & \multicolumn{2}{l|}{} \\
\hline & $\begin{array}{l}\text { Rake } \\
\text { Angle } \\
\left(\alpha^{0}\right)\end{array}$ & $\begin{array}{l}\text { Depth of } \\
\text { Cut } \\
(\mathrm{mm})\end{array}$ & $\begin{array}{l}\text { Cutting } \\
\text { Speed } \\
(\mathrm{m} / \mathrm{min})\end{array}$ & $\begin{array}{l}\text { Rake } \\
\text { Angle } \\
\left(\alpha^{0}\right)\end{array}$ & $\begin{array}{l}\text { Depth of } \\
\text { Cut }(\mathrm{mm})\end{array}$ & $\begin{array}{l}\text { Cutting } \\
\text { Speed } \\
(\mathrm{m} / \mathrm{min})\end{array}$ \\
\hline 1 & 50.01 & 48.81 & 50.33 & 321.7 & 278.2 & 334.7 \\
\hline 2 & 49.83 & 50.61 & 50.29 & 312.5 & 342.8 & 331.3 \\
\hline 3 & 50.89 & 51.31 & 50.12 & 356.5 & 369.7 & 324.7 \\
\hline Delta & 1.06 & 2.50 & 0.22 & 44.0 & 91.5 & 10.0 \\
\hline Rank & 2 & 1 & 3 & 2 & 1 & 3 \\
\hline
\end{tabular}

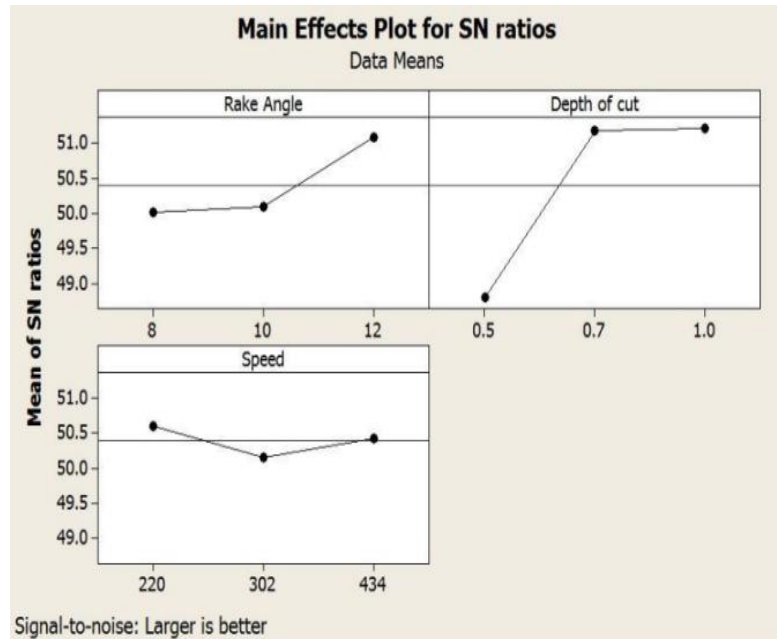

i. Main effect plot for $\mathrm{SN}$ ratio

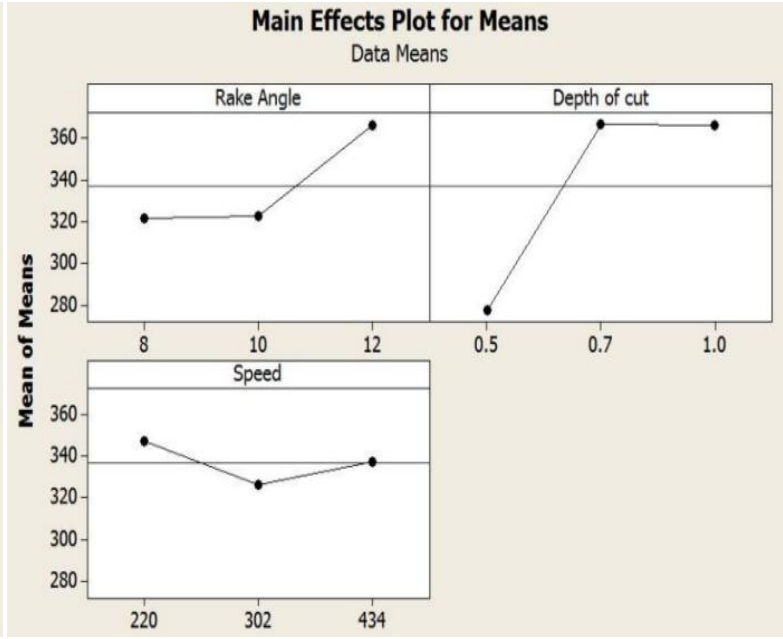

ii. Main effect plot for Mean

Fig. 7. Effect of machining parameters on residual stresses

Higher signal to noise ratio value represents the better performance and it minimise effect of noise factors in model. The main effect plots of signal to noise ratio and means shows increasing graph of rake angle and depth of cut for residual compressive stresses which useful for improving surface integrity of product. This increase in compressive residual stresss will help in improving fatigue strength of material [9, 11 and 13]. Therefore level 3 optimized for $12^{0}$ rake angle and $1 \mathrm{~mm}$ depth of cut. In case of increase in cutting speed reduces the main effect plot of signal to noise ratio and means. Therefore it found reduction in compressive residual stresses [6]. Hence $1^{\text {st }}$ level was optimizing for lower cutting speed of $220 \mathrm{~m} / \mathrm{min}$.

\section{Conclusions}

The comparative study between simulated result and experimental results are closed to each other at near to surface finish which clearer from their percentage error. The corollary situation very difficult to measure accurate experimental residual stresses as depth increases from surface.

Taguchi experimental design responded optimum process parameter of depth of cut and rake angle which main influences in increase in compressive residual stress. Taguchi approach provided rake angle $12^{0}$, depth of cut $1 \mathrm{~mm}$, and cutting speed $220 \mathrm{~m} / \mathrm{min}$ for effective machining on shaper tools. 


\section{Future Scope}

i. Dynamic- elastic tool material can be used instead of making rigid structure for tool analysis to find out better optimum geometrical variables and cutting conditions.

ii. Flank and crater tool wear can be predicted by FEA modelling to understand significant undesirable effects in cutting operations.

iii. Temperature effects can be considered to analyzed effect of cutting zone.

iv. Residual stress analysis can be carried out using oblique cutting processes instead of orthogonal cutting operations.

\section{References}

[1]. Serope Kalpkjean,"Manufacturing Engineering Technology", Third Edition, 1995.

[2]. https://en.wikipedia.org/wiki/Shaper

[3]. R.M. Saoubia, J.C. Outeirob, B. Changeuxa, J.L. Lebruna, A. Morao Dias, 'Residual stress analysis in orthogonal Machining of standard and resulfurized AISI 316L steels', Journal of Materials Processing Technology 96 (1999), pp- 225-233

[4]. E.K. Henriksen, "Residual stresses in machined surfaces", Transactions ASME 73 (January 1951), pp265-278

[5]. K. Okushima, Y. Kakino, "A study on the residual stress produced by metal cutting”, Memoirs of the Faculty of Engineering, Kuyoto 34 (1972), pp.234-248

[6]. Y. Matsumoto, M.M. Barash, C.R. Liu, "Effect of hardness on surface integrity of AISI 4340 steel", ASME Journal of Industrial Engineering 108 (1986), pp.169-175

[7]. Virginia Garcia Navas, Oscar Gonzalo, Ion Bengoetxea, "Effect of cutting parameters in the surface residual stresses generated by turning in AISI 4340 steel” International Journal of Machine Tools \& Manufacture 61,pp.48-57, 2012

[8]. Suleyman Neseli, Suleyman Yald1z, Erol Turkes, "Optimization of tool geometry parameters for turning operations based on the response surface methodology" Measurement 44,pp. 580-587, 2011

[9]. M. Dogra,V. S. Sharma, J. Dureja, "Effect of tool geometry variation on finish turning - A Review" Journal of Engineering Science and Technology Review 4 (1), pp.1-13, 2011

[10]. J. E. Wyatt and J. T. Berry, “A New Technique for the Determination of Superficial Residual Stresses Associated with Machining and Other Manufacturing Processes, ” Journal of Materials Processing Technology, Vol. 171, No. 1, 2006, pp. 132-140.

[11]. M.H. El-Axir, "A method of modeling residual stress distribution in turning for different materials', International Journal of Machine Tools \& Manufacture 42 (2002) pp.1055-1063

[12]. C.R. Liu, Y.B. Guo, 'Finite element analysis of sequential cuts and Tool chip friction on residual stresses in a machined layer', International Journal of Mechanical Sciences 42 (2000), pp.1069-1086

[13]. M. Cebron, F. Kosel, J. Kopac, 'Effect of cutting on surface hardness and residual stresses for 12Mn austenitic steel', Journal of Achievements in Materials and Manufacturing Engineering 55/1 (2012), pp.80-89

[14]. Eyup Bagci,"3-D Numerical Analysis of Orthogonal cutting Process via Mesh free Method", International Journal of Physical Science, vol-6, (2011) 1267-1282.

[15]. I. Lazoglu, D. Ulutan, “An Enhanced Analytical Model for Residual Stress Prediction Machining”, CIRP Annals, Manufacturing Technology (2008) 81-84 